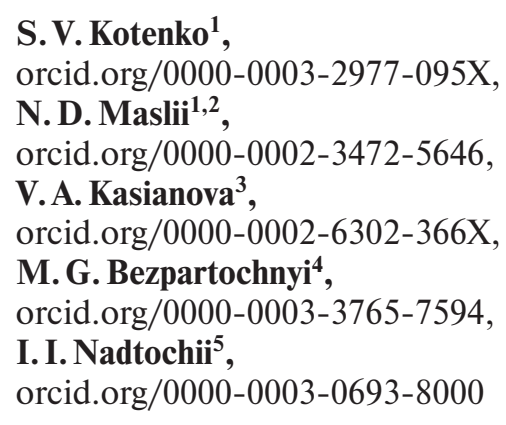

1 - Institute of Market Problems and Economic-Ecological Research of the National Academy of Sciences of Ukraine, Odesa, Ukraine

2 - Odessa I.I. Mechnikov National University, Odesa, Ukraine, e-mail: masliy.natalia@gmail.com

3 - Private institution of higher education "Odessa University of Technology "Shah"”, Odesa, Ukraine

4 - National Aerospace University named after N. Zhukovsky

"Kharkiv Aviation Institute", Kharkiv, Ukraine

5 - Admiral Makarov National University of Shipbuilding, Kherson Branch, Kherson, Ukraine

\title{
OPTIMIZATION OF THE MANAGEMENT SYSTEM FOR MITIGATING THE CONSEQUENCES OF WATER AREA POLLUTION DURING THE CRISIS
}

Purpose. The study is aimed at optimizing and reducing delays in crisis situations in the operation of decision support systems to eliminate the consequences of pollution of water areas.

Methodology. The presented study uses the fundamental provisions of modern science to find the optimal solution in crisis situations. Methods of abstraction and mathematical formalization were used to solve the problem of minimizing the delay time of information packets in providing critical information in conditions of overloading information channels.

Findings. It has been proven that a decrease in the volume of losses is possible in the case of effective management of the elimination of pollution, prompt minimization of its consequences. It has been established that the effectiveness of management to minimize the consequences of an accident is determined by the effectiveness of the information system, and largely depends not only on relevant information, but also on the timeliness of its receipt by the subject of decision-making. A mathematical model and an algorithm for optimizing information flows have been created, which provide minimal delays in obtaining information even under conditions of extreme load of the information system. It has been proven that the task of effective management of an information system can be reduced to minimizing the delay in the provision of critical information. As a result of the study, it was found that for a large information system, which includes more than forty subunits and satellite systems, the use of the proposed approach provides a decrease in the response delay to an information request of time, which does not exceed a minute.

Originality. To prevent delays in the operation of the information management system for the elimination of pollution of water areas, a scientific and applied approach to optimize the information system is proposed, which uses the theory of graphs and Ant Colony Optimization Algorithm and implements effective management of information flow. A mathematical model and an original algorithm have been developed that allow reducing delays in work and providing a resource utilization factor better than the existing analogues.

Practical value. The presented approach will make it possible to increase the efficiency and reliability of information systems for managing technogenic pressure on water areas in crisis situations, reduce the time for providing the necessary information and, thereby, reduce the consequences of pollution and the costs associated with their neutralization. The data obtained in the course of the study are approximated by a polynomial equation, making it possible to evaluate the effectiveness of using the proposed method depending on the number of nodes of the information system and the requirements for limiting the delay time of information.

Keywords: man-caused load, marine environment, management, information system, algorithm

Introduction. The issue of creating a modern information management system for man-made loads on the marine environment is due to several reasons. The first is the growing degradation of the environmental situation in the adjacent waters of the Black and Azov Seas, as stated in the Law of Ukraine "On the Basic Principles (Strategy) of State Environmental Policy of Ukraine for the period up to 2030". Reducing the use of marine bioresources as well as reducing the recreational opportunities of the coast leads to a reduction of relevant industries, economic losses, threats to human health and life. The second reason is Ukraine's commitments to the world community, ratification of relevant international agreements. The third reason is the growing load on maritime transport routes, due to the special status of Ukraine as a transit country for proximity to international transport corridors. This necessitates not only the strengthening of water monitoring but also the proper efficiency in making management decisions on water pollution by transport vessels. As you know, there is a very short period of time, the so-called "Window" for decisionmaking to eliminate the effects of pollution, because wind, storm dispersal of surface pollution has a significant dynamics. The presence of currents, emission conditions, etc. also contributes. According to expert data, the decision-making win-

(C) Kotenko S. V., Maslii N. D., Kasianova V.A., Bezpartochnyi M. G., Nadtochii I. I., 2021 dow can be $1-4$ hours. Therefore, reducing the time for making decisions determines their efficiency and reduces the rate of specific marine pollution [1]. This, in turn, will reduce the specific damage indicator [1], an indicator of associated costs for cleaning the surrounding areas, reducing the probable damage from coastal pollution.

Literature review. Both domestic and foreign scientists have dealt with the problems of man-caused impact on the water area. Various aspects of the problem have been studied. Some of them are used in this research. In the scientific work [2], the index approach to an estimation of level of danger for water area is offered. The article [3] systematizes the causes and results of man-made impact on water systems. The approximation of the Ukrainian system of surface water monitoring and regulation to EU law has been studied [4]. Examples of regional pollution control and assessment systems have been studied for Nigeria [5], Turkey [6], the Persian Gulf [7]. More global systems, in particular for the Arctic seas are considered [8]; the territorial waters of Australia are studied in detail [9]. Of interest is the study on the test decision support system (DSS) for pollution in the Ligurian Sea [10]. Contamination of surface waters with petroleum products, on which the authors of this study relied, is described in detail in scientific papers to varying degrees, under different circumstances. For example, DSS for Monitoring Small Scale Oil Spills [11], tanker accident model is a Bayesian network [12], POSEI- 
DON Mediterranean DSS [13], oil spill modeling to protect coastal communities and the environment of the Eastern Mediterranean Sea [14]. The work is devoted to the question of peculiarities of work of information systems of management of technogenic safety, their viability [15]. The problem of combining environmental impact management into a single DSS of different information systems, for the design of which different models were used, is studied [16]. The efficiency of distributed systems in public administration is studied [17].

In all these scientific works, various aspects of water pollution management have been widely studied, but the definition of such a parameter of information system efficiency as the efficiency of information provision and methods that ensure this have been neglected. In addition, there are no references in the available literature to the presence of software fuses traffic jam DSS, designed to work in conditions of spasmodic increase in information traffic. Such an increase in traffic is typical during man-made accidents. Traditional approach - capacity redundancy cannot guarantee uninterrupted operation under unpredictable information load. As shown by the analysis of literature sources in the design of DSS for marine pollution management, scientists pay little attention to their difference from other technological DSS.

Purpose. The aim of the study is to form a quality management of man-made load on the marine environment, which is provided by effective management of information flows with a sudden increase in the load on the information system in the event of a critical situation.

Methods. The presented research uses the fundamental provisions of modern science to find the optimal solution in crisis situations for many target functions. Methods of abstraction and mathematical formalization were used to solve the problem of minimizing the delay of information packets in providing critical information under conditions of information channel overload.

Results. Comparative analysis DSS for marine pollution management. The analysis showed that their differences should be taken into account when designing DSS for marine pollution management: probable growth by orders of magnitude of the number of users during the crisis; there are several decision-making centers, which leads to additional workload in case of accidents; there is a need to connect information resources of considerable capacity; different technological standards of DSS segments; information can be significant (for example, vector satellite images); significant peak capacity is required only at the time of the accident. Solving the problem by reserving DSS resources for peak load needs requires, firstly, significant costs, and secondly, does not guarantee uninterrupted operation, which is connected, in particular, with unforeseen circumstances of accidents, variability of parameters and structure of DSS.

The analysis showed that the most effective, in terms of controllability are special local systems designed to control relatively small areas and large systems that are created and operated by a group of countries. Indeed, on the one hand, it is easier for a small controlled area to identify the fact of pollution, the source, the culprit of the pollution and to make an effective decision on the elimination of the consequences quickly enough. On the other hand, the global system allows efficient use of resources to form a surveillance network, investigate the causes of pollution and identify violators in difficult hydrometeorological conditions, even beyond the geographical boundaries of national monitoring systems.

Examples of local systems are the Odesa water area monitoring system [18], the mouths of the Dnipro and Southern Buh rivers [18] and Seaway Smart Release, which is responsible for water control near the city of Gold Coast, Australia [19].

An example of a national system is the POSEIDON system in Greece [13]. The obvious disadvantage of this system is the difficulty of taking into account non-national sources of pollution, which play a significant role for the Greek adjacent waters. For example, this is the impact of bottom currents, which carry pollution into Greek waters from the Atlantic Ocean, threatening the main sectors of the national economy - tourism and fisheries.

An example of a supranational system is SeaDataNet. It is a unified standardized information system of the European Union. The introduction of SeaDataNet has made it possible to use a little more than a hundred such centers instead of more than 600 national, scientific and local data centers. The history of the creation and gradual improvement of SeaDataNet allows you to identify trends and steps needed to implement an effective national system.

Conclusions and suggestions of comparative analysis. Conclusions and suggestions that can be made on the basis of the analysis:

- data should be obtained using standardized methods and protocols agreed with neighboring partner countries, which facilitates data exchange;

- the relevance of incoming data streams should be checked and verified;

- data processing and storage should be carried out according to unified methods;

- data must be ready for publication on authorized requests on channels with adequate bandwidth;

- the benefits of data and the efficiency of the national information system increase significantly if it interacts properly with the relevant information systems of neighboring countries;

- the operation of the system should be determined by efficiency and be focused on operations with metadata, provide technical and semantic cooperation with specialized local, specialized and scientific information systems, primarily in relation to marine waters.

Using the $6^{\text {th }}$ Framework Program of the European Union and the grant agreement 283607 SeaDataNet has been improved to a unified and standardized information system, formed on a network basis for obtaining, processing and managing large information resources, both on the state of the waters of the seas and oceans adjacent to the Eurozone countries, and on the main sea transport routes.

The latest restructuring of SeaDataNet in accordance with the grant agreement 730960, under the EU program H2020 is, using cloud and other modern information technologies, the formation on the basis of elements and structure of SeaDataNet actually a new generation SeaDataCloud system. As the study showed, all these steps to improve SeaDataNet, factors and capabilities of the system are largely due to the quality of its design and the efficiency of information flow management in the information system.

Thus, the task of forming an effective information system can be considered as a task of managing information flows.

Streams of input information are formed during the automated continuous monitoring of adjacent waters using a significant number of primary specialized systems for collecting and processing environmental, meteorological, hydrological and other information. These systems for the task are located at considerable distances and distribution over large areas. Collection of information in Ukraine is carried out by different departments and organizations, so the information is spread over different databases. To form a complete and relevant picture of the state of the waters, a comparative analysis requires the use of auxiliary information flows between databases.

In the event of an accident or crisis, the number of measurements per unit time should be significantly increased. This increases the load on the information transmission channels. It is difficult to predict the excessive level of this type of load on the DSS, as it is formed by different requirements for monitoring a particular crisis situation and its features. This increases the importance of effective management of information flows in such systems. As the analysis shows, one of the most common types of pollution caused by ships, in particular in the 
waters of the port of Odesa, the mouths of the Dnipro and Southern Buh rivers, and so on, is oil pollution. Therefore, on the example of pollution of water areas by oil products we will carry out the analysis of economic consequences of pollution of water areas and, according to it, form the concept of "efficiency of information system of management of technogenic load on marine environment".

Efficiency criteria DSS for marine pollution management. Due to the fact that in the normative documents and scientific literature there are no proven methodological recommendations for integrated economic assessment of the consequences of water pollution by petroleum products, we will systematize the economic losses caused by pollution and link them to the indicator of information system efficiency. Penalties paid by ship owners for environmental pollution (in particular, oil spills), even if they are collected without dispute, will not be able to compensate for long-term costs associated with the consequences of water pollution, because their volume, the number of business entities that will be harmed, cannot be predicted when the fact of massive, catastrophic spill of oil products is detected.

To establish the relationship of environmental and economic indicators: specific pollution, specific damage, associated costs of pollution with indicators of the efficiency of the information system was analyzed. This is quite technically difficult, as the damage from accidents strongly depends on the circumstances and place of the accident, weather and hydrodynamic conditions, and others. This led to a weak correlation between the numerical values of environmental, economic and information indicators. But it is established that practices for such accidents use the index "decision window" (inevitability point) which is defined by limit values of the named factors.

The analysis proved that the differences of DSS for marine pollution management cause the difference of efficiency indicators of this information system. That is, even the classic performance indicators of DSS with variable load, for example, the so-called "Peak system bandwidth", in this case are not relevant enough. In particular, the use of "peak system bandwidth" with an adaptive control mechanism. The solution is to create special algorithms for managing DSS data flows in a crisis. And the criterion for the effectiveness of DSS for marine pollution management is the ability to avoid traffic jam. Therefore, in this case, the numerical performance indicator DSS was chosen to minimize the delay time.

Analysis of Fig. 1 indicates the presence of a direct causal chain: the more effective the decisions to minimize the effects of pollution are, and the more efficient the actions to collect petroleum products at the place of their spill are, the smaller the long-term economic consequences will be. And the effectiveness and efficiency of decisions in crisis conditions is determined by the equality of all other conditions for data reliability, the efficiency of providing information to decision makers.

Thus, the effectiveness of management, which in accordance with Fig. 1 determines the economic efficiency of the information system, depends largely not only on the relevance of information, but also on its timeliness of its receipt by the decision-maker. That is, the effective management of the information system man-made load on the marine environment can lead to minimization of the delay time in the provision of critical information. This requires the creation of an appropriate algorithm.

Algorithm of mathematical formalization of the problem. To do this, we analyze the information system using the method of graph theory. In such a system, centers of production, information retrieval, concentration and processing can be considered as graph nodes. Like ribs - ways of transmitting information. Critical from the point of view of an estimation of efficiency of the system will be receipt of streams of information, first of all to knots which further we will name as knots of users of system. These nodes will be distributed, but to simulate the

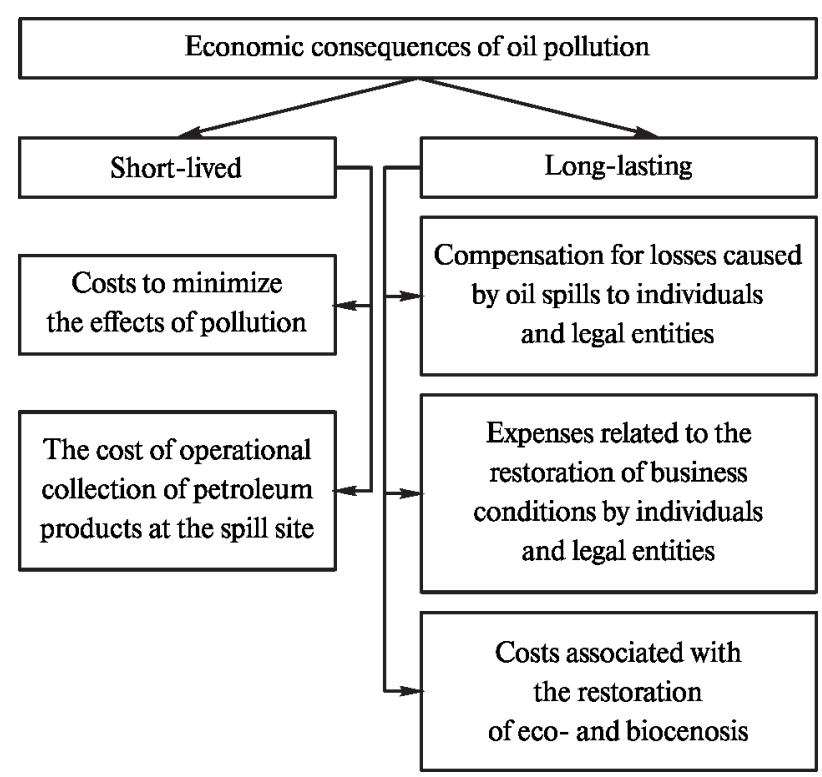

Fig. 1. Systematization of economic consequences of water pollution by oil products

system we can consider them as a single output node, which is associated with real user nodes with zero-weight edges. The volume of the information package received by the user can also be considered as a weighted average - because the packages of such an information system for standardized queries will not differ significantly in volume. In this case, the time between sending the request and the response received from the system will be critical from the point of view of evaluating the efficiency of the system. Experience with complex information systems shows that the response time in standard operation is very different from the response time from an overloaded system. Even well-designed systems require significant resources, funds, and time to beta test. And, even a conducted beta test cannot guarantee failure-free operation of the system in crisis conditions, and these conditions, without recurrence of all components of the crisis, may reveal new weak points of the system each time. The weak point, in this case, will be called the bandwidth of each of the edges of the graph, which uses the simulated system. Let us denote it by an integral function $\omega(x) \geq 0$, where $x$ is the number of information packets that will pass per unit time through each edge. Obviously, $\omega(x)$, in this case plays the role of so-called "rib scales".

For each of the edges $\omega^{\text {input }}(x)=\omega^{\text {output }}(x)$, and for the system as a whole in equation (1) it is

$$
\sum_{i}^{n} \omega_{i}^{\text {input }}(x)=\sum_{j}^{m} \omega_{j}^{\text {output }}(x) .
$$

Since each of the edges has a limited bandwidth, then $\vartheta \leq$ $\vartheta^{\text {max }}$, where $\vartheta^{\text {max }}$ is the maximum number of standard packets of information that can pass through the edge per unit time. Thus, the weight of the edge will be a function of time: $\omega(x)=f(t)$. The weight of the route for obtaining information by the user will be equal to the weight of all the edges that are part of this route. You can also use the expression for the route as a whole $\vartheta \leq \vartheta^{\mathrm{max}}$, then, to fulfill this condition, the problem, from the point of view of graph theory, is reduced to the problem of constructing a flow control graph (CFG).

The information system for managing the man-caused load on the marine environment will be complex in Ukrainian realities. So, it will be formed from many subsystems, have a significant number of satellite information systems, databases, and so on. To optimize the system, minimize the response time to the request (which is a critical factor for an interactive decision-making system in the management of man-made 
load on the marine environment, which is also due to crises, accidents and catastrophes), various mathematical methods are used. In particular, the methods of Markov analysis are used. In our opinion, this narrows the number of possible states of such extremely complex systems as the one under consideration, because the control of a multi-fragment Markov graph is faced with the need to analyze hundreds of its states, which limits the possibilities of its study. The unwillingness of the system to work in conditions of overload of a complex network of information channels with a given degree of efficiency can be detected in a crisis situation, because beta testing to verify all the complexities of using the system in operation is impossible. This, in turn, will lead to uncontrollability of water pollution in a real emergency.

To form a self-learning system that can, due to the excessive time of implementation of a solution, use information transmission routes that were recognized as insufficiently effective when creating and testing the system, or find the original route, we proposed to use the Ant Colony Optimization Algorithm [20].

Indeed, when testing the system, it is possible to determine certain routes that will be considered the best under the starting conditions (for example, to respond to a request faster). Catastrophe, accident, etc. in the controlled area will lead to a sharp increase in information flows in certain parts of the system, on certain chains, previously optimal routes. Then, routes that were previously identified as ineffective may come in handy. But the system must find them itself.

We have proposed a CFG algorithm that can generate a parallel sending of information packets, duplicating them, on different routes with an estimate of the time of passage of each packet. In the event that the time of passage of the main information flow exceeds a certain, defined limit, the information will be sent along the route that showed the best of the results. That is, the choice of route follows the time parameter on the interval $\left(t_{\min } \leq t \leq t_{\max }\right)$ and $t_{\max } \in\left(t_{\max }^{\mathrm{lim}}, t_{\max }^{\text {route }}\right)$, where $t_{\min }$ is the shortest time of passage of information, $t_{\max }$ is the largest time of passage of information, $t_{\max }^{\mathrm{lim}}$ is the maximum time of passage of the information is set, $t_{\max }^{\text {route }}$ is the largest time of information passing, determined iteratively by comparing the time of providing information on different competitive routes.

This principle implements, in a way, the "pheromone" path by analogy with an ant, which marks its path with a pheromone. Successors go where pheromones are stronger, because it indicates that there were more "ants" in the closest time, so that is the best way.

Thus, this principle implements one of the variants of the class of genetic algorithms. The test packet passes randomly along the route, which is described by a linear matrix of vertices of the oriented graph, each of which is a node of successive chains that make up the route, and a linear matrix of time intervals that determine, with a given accuracy, the packet time of each edge connects pairs of consecutive vertices (so-called "weight" of an edge). Significant riding time automatically means searching for an alternative circuit with an estimate of the time of its passage, comparing the time on the main and alternative circuit and selecting a circuit with a smaller value.

The algorithm is built so that the number of "pheromones" on the path will be proportional to the number of packets which have passed this way.

This is implemented as follows: each packet has an index file where all the links of its route are fixed. The route runs from the bifurcation point $i$ to the consumer $j$. By comparing the packet travel time and selecting the smallest one, we estimate the number of packets of information passing each path and select the largest value, thus estimating the bandwidth of the new path. And subsequent requests are accompanied by an index file, which indicates the selected route.

An example of the problem is that $\vartheta$ queries and answers to the mats tarting speed $v$ follow the route (of the total number of routes $a \in(s, l))-s\left(\varphi_{i s}\right)$ or $l\left(\varphi_{i l}\right)$ for time, respectively, $t_{s}$ and $t_{l}=r \cdot t_{s}$ and, thus, the probability, which is a function of the time of passage of the information packet, $p_{j s}(t)$ or $p_{j l}(t)$, that the packet at the bifurcation point will choose the path $s$ or $l$ will depend on the amount of "pheromone" $\varphi_{i a}(t)-$ that is, the indices of the packets of information on each path. Then, for example, for $a=2(2-4)$.

$$
\begin{gathered}
\frac{d \varphi_{i s}}{d t}=\vartheta p_{j s}\left(t-t_{s}\right)+\vartheta p_{i s}(t) ; \\
\frac{d \varphi_{i l}}{d t}=\vartheta p_{j l}\left(t-r \cdot t_{s}\right)+\vartheta p_{i l}(t),
\end{gathered}
$$

for fulfilling the condition

$$
\sum p_{i a}(t)=1
$$

The block diagram of the proposed algorithm is presented in Fig. 2. Two networks were used for beta testing: 192 nodes and 375 branches, and 214 nodes and 412 branches. On the first number of nodes varied to a minimum in groups of 10 units to identify the effect of their number on the result. Congestion occurred on routes 10-20\% higher than the capacity of the most vulnerable branches of each of the routes. Routes were selected using a random number generator. Generation interval $\sim 0.5-5 \mathrm{~s}$. This confirmed the effectiveness of the algorithm.

Differences of the offered algorithm from others: not a pheromone, but a pheromone trace is formed (the delay of a package on a branch is minimized); limiting the weight of the branches are adaptive; the approach is not iterative, but iterative-communication - parametric randomized greedy algorithm is only a segment of the integrated algorithm. The operation of the integrated algorithm is as follows. Each consumer node tests the time between the request and the response. For exceeding the adaptive level of the minimum delay $t \geq t_{\max }$ branches of routes to this node are tested by packages-ants which estimate a delay on each of them. Next, the controller redistributes flows, optimizing traffic. This counter-audit reduces the integrated system load from additional adaptive routing, simplifies flow redistribution management, and speeds up congestion adaptation. The delay time is minimized on the graph $G(V, E)$ where $v_{k}, v_{n} \in V$ are reception-transmission nodes, $e_{k n} \in E$ are branches between these nodes. The weight is set for the branches - the delay time. When the time is too long the branch falls into the taboo list. During the "evaporation of the pheromone", the branch begins to be tested again by ANT-test. When traffic is normalized, the branch

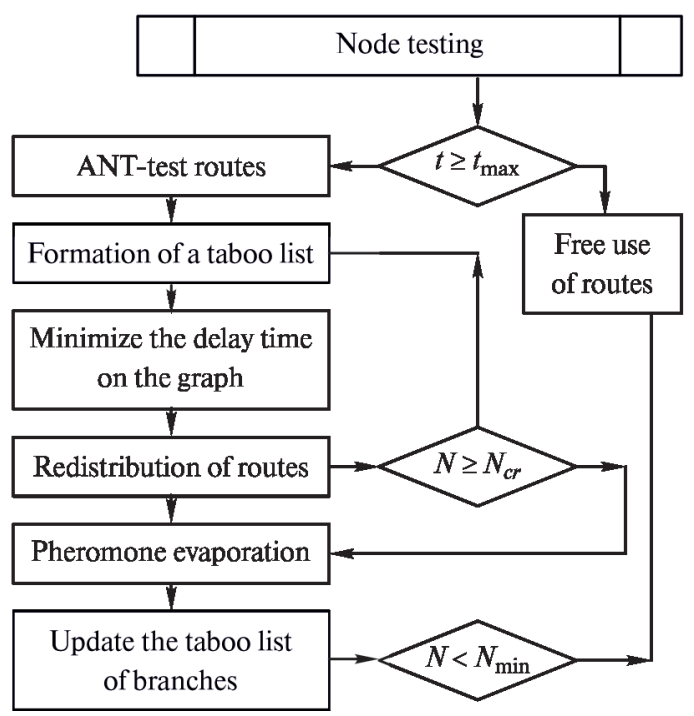

Fig. 2. Integrated adaptive routing algorithm 
is removed from the taboo list. When clogging occurs at a critical number of nodes $N_{c r}$ the time limit becomes adaptive that is, the intervals of the allowable weight of the branches change. This allows you to use routes with the "best of the worst" weights of the branch.

The formed mathematical approach makes it possible, considering the variability of routes $a$ to find the dependence of the time of packets on the number of nodes using this technique, given, for example, that the maximum time is determined, which expertly determined the limit for packets 30 minutes.

Advantages over the closest analogues involve BI applications [21] and the design value for DSS [22] in terms of utilization of the $i^{\text {th }}$ resource, respectively, 1.8 and 2.3 times, and is 0.42 . This result in a small window of opportunity can be crucial.

Of course, the limit value can be changed by the system administrator, depending on the circumstances of the real situation.

Fig. 3 shows the results of the reduction of the delay time of the information packet, provided that the application of the proposed algorithm depending on the number of system nodes. Increasing the number of system nodes allows you to increase the number of options for routes of information transmission.

This dependence was approximated by a polynomial (5).

$$
\begin{gathered}
y=-0.0109 x^{6}+0.3223 x^{5}-3.7632 x^{4}+21.702 x^{3}- \\
-61.754 x^{2}+68.447 x+5.0625 .
\end{gathered}
$$

As the calculation shows, for the number of nodes of the information system greater than forty, the use of the proposed approach reduces the delay in responding to the information request to a time not exceeding one minute.

The use of equation (5) makes it possible to estimate the need to use the proposed method depending on the number of nodes of the information system and the requirements for limiting the delay time of the response to the user's request.

Thus, the introduction of the proposed approach makes it possible to quickly obtain information on pollution in accordance with changing hydrological, atmospheric conditions, accident circumstances, and so on. This, in turn, will provide an opportunity to quickly localize pollution, minimize its consequences.

Conclusions. The study on information systems designed to manage man-made load on the marine environment in other countries has identified trends in the formation of such systems, the requirements for their modification that arise over time and the stages of their development. This made it possible to propose concrete proposals and formulate concrete recom-

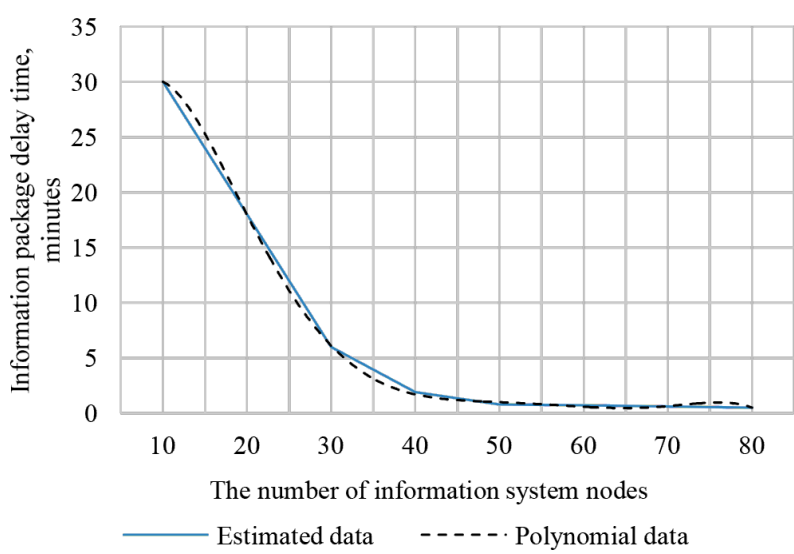

Fig. 3. Reduction of time of delay of an information package in the conditions of crisis for use of the offered Ant Colony Optimization Algorithm mendations necessary for the implementation of an effective national system. The systematization of economic consequences of water pollution by oil products, as the most widespread type of pollution in territorial waters of Ukraine with long-term ecological and economic consequences allowed establishing that reduction of costs is possible in case of an effective management of the elimination of pollution and operative minimization of its consequences. It is established that the effectiveness of man-made load management on the marine environment, which determines the economic efficiency of the information system used for this, largely depends not only on the completeness and accuracy of information, but also on the timeliness of its receipt. Thus, the effective management of the information system on man-made load on the marine environment can lead to minimization of the delay time in providing critical information.

To do this, it is necessary to introduce algorithms for managing information flows, which would reduce the time of passage of information packets to the user in case of disasters and accidents with significant consequences. During this period, the load on the information system increases abruptly, which, with a fixed bandwidth of channels, significantly increases the time of its provision to the user. To minimize the delay time of information packets, it is proposed to apply a mathematical approach developed for this purpose. This approach uses the graph theory and the Ant Colony Optimization Algorithm and is reduced to the problem of constructing a flow control graph. The study found that for a large information system, which includes more than forty nodes, the use of the proposed approach reduces the delay in responding to the information request to a time not exceeding one minute. The obtained data on the delay of information packets are approximated by a polynomial equation. This makes it possible to assess the need and efficiency of the proposed method at the design stage depending on the number of nodes of the information system and the requirements to limit the delay time of the response to the user's request. The proposal for the next stages of the study is to agree with neighboring partner countries on methods of proper cooperation in forming channels for fast and reliable transmission of standardized information according to standardized protocols, developing methods for working with metadata, exchange of semantic information on man-made loads in adjacent sea areas.

\section{References.}

1. Burkinsky, B.V., Ilchenko, S.V., Rubel, O.E., \& Kotenko, S.V. (2020). Information and analytical support for the protection of the marine environment from man-made impact, according to the general ed. Burkinsky B. V.; NAS of Ukraine, Inst. market and econ.-ecol. research. Odesa: IPREED NASU.

2. Bezsonov, Ye., Andreev, V., \& Smyrnov, V. (2016). Assessment of safety index for water ecological system. Eastern-European journal of enterprisetechnologies, 6/10(84), 24-34.https://doi.org/10.15587/17294061.2016.86170.

3. Udod, V., Madzhd, S., \& Kulynych, Ya. (2017). Regional features of structural and functional properties of technogenically transformed aquatic ecosystems. Transactions of Kremenchuk M. Ostrohradskyi National University, 3(1), 93-99.

4. Uberman, V., \& Vaskovets, L. (2018). Approximation of the system of determination, assessment and regulation of surface water quality to EU law. Sustainable Development - state and prospects: proceedings of the international scientific symposium SDEV'2018, 63-66. Retrieved from http://ena.lp.edu.ua:8080/handle/ntb/43230.

5. Iduk, U., \& Nitonye, S. (2015). Effects and Solutions of Marine Pollution from Ships in Nigerian Waterways. International Journal of Scientific and Engineering Research, 6(9), 81-90.

6. Özdemir, Ü., \& Yilmaz, H. E. (2016). Investigation of Marine Pollution Caused by Ship Operations with DEMATEL Method. International Journal on Marine Navigation and Safety of Sea Transportation, 10(2), 315-320. https://doi.org/10.12716/1001.10.02.14.

7. Mokhtari, S., Hosseini, S.M., Danehkar, A., Azad, M.T., Kadlec, J., Jolma, A., \& Naimi, B. (2015). Inferring spatial distribution of oil spill risks from proxies: Case study in the north of the Per- 
sian Gulf. Ocean \& Coastal Management, 116, 504-511. https://doi. org/10.1016/j.ocecoaman.2015.08.017.

8. Nevalainen, M., Helle, I., \& Vanhatalo, J. (2017). Preparing for the unprecedented - Towards quantitative oil risk assessment in the Arctic marine areas. Marine Pollution Bulletin, 114, 90-101. https://doi. org/10.1016/j.marpolbul.2016.08.064.

9. Byrnes, T. A., \& Dunn, R.J.K. (2020). Boating- and ShippingRelated Environmental Impacts and Example Management Measures: A Review. Journal of Marine Science and Engineering, 8(11), 908. https://doi.org/10.3390/jmse8110908.

10. Grasso, R., Cococcioni, M., Mourre, B., Chiggiato, J., \& Rixen, M. (2012). A maritime decision support system to assess risk in the presence of environmental uncertainties: the REP10 experiment. Ocean Dynamics, 62, 469-493. https://doi.org/10.1007/s10236-011$\underline{0512-6 .}$.

11. Moroni, D., Pieri, G., \& Tampucci, M. (2019). Environmental Decision Support Systems for Monitoring Small Scale Oil Spills: Existing Solutions, Best Practices and Current Challenges. Journal of Marine Science and Engineering, 7(19), 1-17. https://doi.org/10.3390/ jmse7010019.

12. Jolma, A., Lehikoinen, A., Helle, I., \& Venesjärvi, R. (2014). A software system for assessing the spatially distributed ecological risk posed by oil shipping. Environmental Modelling \& Software, 61, 1-11. https://doi.org/10.1016/j.envsoft.2014.06.023.

13. Zodiatis, G., De Dominicis, M., Perivoliotis, L., Radhakrishnan, H., Georgoudis, E., Sotillo, M., ..., \& Clementi, E. (2016). The Mediterranean Decision Support System for Marine Safety dedicated to oil slicks predictions. Deep Sea Research Part II: Topical Studies in Oceanography, 133, 4-20. https://doi.org/10.1016/j.dsr2.2016.07.014. 14. Alves, T. M., Kokinou, E., Zodiatis, G., Radhakrishnan, H., Panagiotakis, C., \& Lardner, R. (2016). Multidisciplinary oil spill modeling to protect coastal communities and the environment of the Eastern Mediterranean Sea. Scientific Reports, 6, 36882. https://doi. org/10.1038/srep36882.

15. Kriazhych, O. O., \& Kovalenko, O. V. (2015). Some issues of sustainability of information technologies of technogenic safety management. Decision support systems. Theory and practice, 170-173.

16. Ievdin, Ye. O. (2015). Methodology of integration of mathematical models of the environment into decision-making support systems. Decision support systems. Theory and practice, 74-77.

17. Kopeichykov, V. V., \& Kovtun, V.A. (2015). Features of assessment of efficiency of distributed networks of situation centers in state administration. Decision support systems. Theory and practice, 135-138. Retrieved from http://conf.atsukr.org.ua/conf_files/conf_dir_24/ Kopeychykov sppr2015.pdf.

18. Sreznevsky, B. (2019). Central Geophysical Observatory. Review of the state of environmental pollution on the territory of Ukraine according to the observations of hydrometeorological organizations in 2019. Retrieved from http://cgo-sreznevskyi.kyiv.ua/index.php? $\mathrm{fn}=\mathrm{u}$ zabrud\& $\mathrm{f}=$ ukraine.

19. DHI (2021). Marine Environment Decision Support. Retrieved from http://www.waterforecast.com/forecastservices/marineenvironmentdecisionsupport.

20. lanas-Sitja, I., Deneubourg, J.-L., Gibon, C., \& Sempo, G. (2015). Group personality during collective decision-making: a multilevel approach. Proceedings of the Royal Society B, 282, 20142515, 1-9. https://doi.org/10.1098/rspb.2014.2515.

21. Dayal, U., Wilkinson, K., Simitsis, A., Castellanos, M., \& Paz, L. (2012). Optimization of Analytic Data Flows for Next Generation Business Intelligence Applications. In: Nambiar, R., \& Poess, M. (Eds.) Topics in Performance Evaluation, Measurement and Characterization. TPCTC 2011. Lecture Notes in Computer Science, 7144, 4666. Berlin, Heidelberg: Springer. https://doi.org/10.1007/978-3-642$32627-14$.

22. Ilchenko, S. V., Kotenko, S. V., \& Kasianova, V.A. (2020). Theoretical-applied principles of formation of information and analytical support of protection of the marine environment from vessel pollution, Economic innovation, 22(4(77)), 73-82. https://doi.org/10.31520/ ei.2020.22.4(77).73-82.

\section{Оптимізація системи управління зменшення наслідків забруднення акваторій в умовах кризи}

\author{
С. В. Котенко ${ }^{1}$, Н. Д. Маслій ${ }^{1,2}$, В. А. Касьянова ${ }^{3}$, \\ М. Г. Безпарточний ${ }^{4}$, I. I. Надточій
}

1 - Інститут проблем ринку та економіко-екологічних досліджень Національної Академії Наук України, м. Одеса, Україна

2 - Одеський національний університет імені I. I. Мечникова, м. Одеса, Україна, e-mail: masliy.natalia@gmail.com 3 - Одеський технологічний університет «Шаг», м. Одеса, Україна

4 - Національний аерокосмічний університет імені М. Є.Жуковського «Харківський авіаційний інститут», м. Харків, Україна

5 - Херсонська філія Національного університету кораблебудування імені адмірала Макарова, м. Херсон, Україна

Мета. Дослідження спрямоване на оптимізацію та зменшення затримок у кризових ситуаціях роботи систем підтримки прийняття рішень щодо ліквідації наслідків забруднення акваторій.

Методика. У представленому дослідженні використані фундаментальні положення сучасної науки щодо пошуку оптимального рішення у кризових ситуаціях. Методи абстрагування й математичної формалізації були використані для вирішення задачі мінімізації часу затримки інформаційних пакетів у наданні критично важливої інформації за умов перевантаження інформаційних каналів.

Результати. Доведено, що зменшення обсягів збитків можливе у разі ефективного управління ліквідацією забруднення, оперативної мінімізації його наслідків. Установлено, що ефективність керування по мінімізації наслідків аварії обумовлюється ефективністю інформаційної системи, значною мірою залежить не тільки від релевантної інформації, але й від своєчасності ії отримання суб'єктом прийняття рішень. Створена математична модель і алгоритм оптимізації інформаційних потоків, що забезпечують мінімальні затримки в отриманні інформації навіть в умовах надзвичайного навантаження інформаційної системи. Доведено, що задачу ефективного управління інформаційною системою можна звести до мінімізації часу затримки в наданні критично важливої інформації. У результаті проведеного дослідження встановлено, що для великої інформаційної системи, яка включає більше сорока субблоків і сателітних систем, використання запропонованого підходу забезпечує зменшення затримки відповіді на інформаційний запит до часу, що не перевищує хвилини.

Наукова новизна. Для запобігання затримок у роботі інформаційної системи управління ліквідацією забруднення акваторій запропоновано науково-прикладний підхід оптимізації інформаційної системи, що використовує теорію графів і Ant Colony Optimization Algorithm та реалізує ефективне управління інформаційним потоком. Розроблена математична модель і оригінальний алгоритм, що дозволяють зменшити затримки в роботі й забезпечити коефіцієнт використання ресурсів краще, ніж наявні аналоги.

Практична значимість. Представлений підхід дозволить збільшити ефективність і надійність інформаційних систем управління техногенним навантаженням на акваторії за кризових ситуацій, зменшити час надання потрібної інформації і, тим самим, зменшити наслідки забруднення й витрати, що пов'язані з їх нейтралізацією. Отримані під час дослідження дані апроксимовані поліноміальним рівнянням, що надає можливість оцінити ефективність використання запропонованого методу в залежності від кількості вузлів інформаційної системи та вимог до обмеження часу затримки інформації.

Ключові слова: техногенне навантаження, морське середовище, управління, інформаційна система, алгоритм

The manuscript was submitted 22.04.21. 